\title{
DDR2 Gene Mutation
}

National Cancer Institute

\section{Source}

National Cancer Institute. DDR2 Gene Mutation. NCI Thesaurus. Code C148104.

A change in the nucleotide sequence of the DDR2 gene. 